\title{
EFFECTS OF BENZO(A)PYRENE EXPOSURE ON THE ATPASE ACTIVITY AND CALCIUM CONCENTRATION IN THE HIPPOCAMPUS OF NEONATAL RATS
}

\author{
KAI YANG ${ }^{1}$, CHENGZHI CHEN ${ }^{1}$, SHUQUN CHENG ${ }^{1}$, XIANQING CAO ${ }^{2}$, and BAIJIE TU ${ }^{1}$
}

Chongqing Medical University, Chongqing, China

${ }^{1}$ Innovation Center for Social Risk Governance in Health, Research Center for Medicine and Social Development, School of Public Health and Management, Department of Occupational and Environmental Health

${ }^{2}$ Center of Experimental Teaching for Public Health, Experimental Teaching and Management Center

\begin{abstract}
Objectives: To investigate whether postnatal benzo(a)pyrene $(\mathrm{B}(\mathrm{a}) \mathrm{P})$ exposure caused the impairments on the process of neurodevelopment and the alteration in the calcium medium in the neonatal rats. Material and Methods: Eighty neonatal Sprague Dawley (SD) rats were randomly divided into 5 groups (untreated control group, vehicle group, $0.02 \mathrm{mg} / \mathrm{kg}$, $0.2 \mathrm{mg} / \mathrm{kg}$ and $2 \mathrm{mg} / \mathrm{kg} \mathrm{B}(\mathrm{a}) \mathrm{P}$-exposed group). Rats were treated with B(a)P by the intragastric administration from postnatal day (PND) 4 to 25. Morris water maze (MWM) was employed to observe the spatial memory of rats. The activity of calcium adenosine triphosphatase $\left(\mathrm{Ca}^{2+}\right.$-ATPase), sodium-potassium adenosine triphosphatase $\left(\mathrm{Na}^{+}-\mathrm{K}^{+}\right.$-ATPase $)$ and calcium-magnesium adenosine triphosphatase $\left(\mathrm{Ca}^{2+}-\mathrm{Mg}^{2+}\right.$-ATPase $)$ in the hippocampus were detected by commercial kits. Fura-2 pentakis(acetoxymethyl) (Fura-2/AM) probe and reactive oxygen species (ROS) reagent kit were used for measuring the concentration of $\mathrm{Ca}^{2+}$ and ROS in the hippocampus synapse, respectively. Results: Rats exposed to B(a)P resulted in the deficits in the spatial memory manifested by the increased escape latency and decreased number of crossing platform and time spent in target quadrant in comparison with the control groups. Benzo(a)pyrene exposure caused the significant decrease in the ATPase activity in the hippocampus and caused $\mathrm{Ca}^{2+}$ overload in the synaptic, besides, the ROS concentration increased significantly which may further induce neurobehavioral impairment of the neonatal rats. Conclusions: Our findings suggest that postnatal B(a)P exposure may cause the neurobehavioral impairments in the neonatal rats, which were mediated by the decreased ATPase activity and elevated $\mathrm{Ca}^{2+}$ concentration. Int J Occup Med Environ Health 2017;30(2):203-211
\end{abstract}

Key words:

Hippocampus, Neurodevelopment, ATPase activity, Ca2 + concentration, Neonatal rats, Benzo(a)pyrene

Funding: this research was supported by the grant of the National Natural Science Foundation of China (NSFC, grant No. 81372957). Grant manager: Prof. Baijie Tu. Received: July 20, 2015. Accepted: January 25, 2016.

Corresponding author: B. Tu, Chongqing Medical University, Innovation Center for Social Risk Governance in Health, Research Center for Medicine and Social Development, School of Public Health and Management, Department of Occupational and Environmental Health, 1 Yixueyuan Road, Yuzhong District, Chongqing 400016, China (e-mail: baijietu@hotmail.com). 


\section{INTRODUCTION}

Benzo(a)pyrene (B(a)P), ubiquitous neurotoxic substance, widely exists in the production and living environment, mainly formed during industrial processes and products manufacturing, such as oil combustion, automobile exhausts, tobacco smoke, broiled foods [1-3]. Benzo(a)pyrene and its metabolites may cross the brainblood barrier because of the highly lipophilic property, and the brain is very hard to eliminate them. Thus, $\mathrm{B}(\mathrm{a}) \mathrm{P}$ exposure may have an advanced impact on the central nervous system (CNS) [4].

Besides its carcinogenicity, some studies have also revealed that $\mathrm{B}(\mathrm{a}) \mathrm{P}$ has neurobehavioral toxicity $[5,6]$. A number of epidemiological studies have shown that children may be more sensitive to neurological poison because of their immature nervous system. Several experimental studies have further revealed that B(a)P could cause the deficits in the process of cognitive development in the infant Sprague Dawley (SD) rats and thus inducing neural impairment [6,7]. Moreover, the gestational exposure to B(a)P may affect the neural development and lead to cognitive decline $[3,8]$.

As an intracellular second messenger, calcium $\left(\mathrm{Ca}^{2+}\right)$ widely distributes in the brain, heart, muscle and endocrine cells. Calcium in the cytoplasm is normally active as the signaling mediator in the numerous cellular processes, including cell proliferation, differentiation, and survival/ death [9]. More importantly, does $\mathrm{Ca}^{2+}$ also play an important role in the regulation of gene expression, muscle contraction and hormone release [10,11].

Calcium flows among intracellular and organelles and cytoplasm constitute the essential mode of action for the various physiological functions of the body. Neuronal cells heavily rely on the strict regulation of intracellular calcium concentration [12]. Cells move free $\mathrm{Ca}^{2+}$ in and out of cells through the transmembrane channel, and control intracellular $\mathrm{Ca}^{2+}$ concentration by many means of calcium transport systems. It is also noteworthy that the elevation of $\mathrm{Ca}^{2+}$ within the cells forms the basis of cellular signal transduction. The presynaptic membrane $\mathrm{Ca}^{2+}$ channel may further mediate $\mathrm{Ca}^{2+}$ influx, and then actualize synaptic vesicle exocytosis and neurotransmitter release [13]. The neurotoxic effects of $\mathrm{B}(\mathrm{a}) \mathrm{P}$ have been gradually realized. However, the details underlying mechanisms are not completely understood. Previous studies demonstrated that one of the main mechanisms of nervous impairments was the inhibition of adenosinetriphosphatase (ATPase) activity as well as the increasing intracellular calcium concentration [14-16]. The increased ATPase activity may markedly enhance the transport capability of $\mathrm{Ca}^{2+}$, and then suppress the occurrence of $\mathrm{Ca}^{2+}$ overload in brain [17]. Calcium overload is the "final common pathway" that causes the neuron damage. As yet, little relevant studies have expatiated the relationship between $\mathrm{Ca}^{2+}$ and neurotoxic effect caused by B(a)P.

Based on these considerations, the objective of this study presented here has been to investigate whether the B(a)P exposure causes the neurodevelopment impairments and the disturbance in the $\mathrm{Ca}^{2+}$ concentration in the neonatal rats.

\section{MATERIAL AND METHODS}

\section{Materials and reagents}

Benzo(a)pyrene (99\% purity), purchased from Sigma-Aldrich Co. (St. Louis, MO, USA), was dissolved in peanut and sonicated for $30 \mathrm{~min}$ at $40^{\circ} \mathrm{C}$. The ATPase detection kits and reactive oxygen species (ROS) detection kit were all obtained from the Nanjing Jiancheng Bioengineering Institute (Nanjing, China). Fura-2 pentakis(acetoxymethyl) (Fura-2/AM) calcium fluorescent probes were purchased from Sigma-Aldrich Co.

\section{Animals and treatment}

Eighty neonatal healthy SD rats, 40 male and female rats, the postnatal day (PND) 4 of age (the day of delivery was considered PND 0), were obtained from the Chongqing Medical University Lab Animal Center. 
The animals were housed in a standard 12:12 $\mathrm{h}$ light-dark cycle with a temperature of $24 \pm 1^{\circ} \mathrm{C}$ and a relative humidity of $50 \pm 10 \%$. Non-toxic dyes were used for numbering and identifying each rat, and then the rats were randomly divided into 5 groups as follows: the control group, vehicle group (penut oil), $0.02 \mathrm{mg} / \mathrm{kg} \mathrm{B}(\mathrm{a}) \mathrm{P}-\mathrm{ex}-$ posed group, $0.2 \mathrm{mg} / \mathrm{kg} \mathrm{B}$ (a)P-exposed group and $2 \mathrm{mg} / \mathrm{kg}$ $\mathrm{B}(\mathrm{a}) \mathrm{P}$-exposed group. Benzo(a)pyrene and solvent were given to the rats by means of the intragastric administration from PND 4 to PND 25.

After treatment, all the rats were redistributed to the original nursing cages. The rats were weaned on PND 21, and these weaned rats were redistributed to cages according to the same-sex and treatment groups. During the experiment period, the body weight, diet, activities and nervous system reactions were recorded.

\section{Morris water maze}

The spatial memory of rats was examined by Morris water maze (MWM). The MWM consisted of a stainless steel circular pool (diameter of $100 \mathrm{~cm}$ and depth of $40 \mathrm{~cm}$ ), filled in with water at the $22 \pm 1^{\circ} \mathrm{C}$, and made opaque by means of the non-toxic white paint. The pool was randomly divided into 4 equal quadrants and a circular platform of $9 \mathrm{~cm}$ in diameter was submerged $1 \mathrm{~cm}$ below the water surface, fixed in the center of one of the 4 quadrants. A video camera was placed above the maze to observe the behavior of animals.

\section{Hidden platform test}

The visualization platform training was conducted before the hidden platform test. All the rats were permitted to swim freely for 120 seconds in the pool without the platform to adapt to the swimming environment. The hidden platform test began the day after habituation. The behavioral test was taken for 6 consecutive days, and each rat was trained for 4 trails per day. For each trail, a rat was gently and randomly placed into one of the quadrants, facing the pool wall. All the rats had been allowed to swim until they found the platform with a maximum allotted time of 60 seconds. If the rat had not found the platform within $60 \mathrm{~s}$, it was guided to the platform by the experimenter and allowed to stay on the platform for 20 seconds. After each trail, the rats were thoroughly wiped dry with a towel and rested for at least $5 \mathrm{~min}$ before the next trail.

Probe test

After the last hidden platform trail, the rats were given a $60 \mathrm{~s}$ probe test of the spatial location without the platform. The numbers of crossing the original platform location and the percentage time spent in the target quadrant were recorded for each rat.

\section{ATPase activity detection}

After the behavioral test, 4 male and female rats were randomly chosen from each group under pentobarbitalsodium anesthesia and the hippocampus was isolated and weighted. Then, the tissues were rinsed and homogenized with ice-cold saline. The tissue homogenates were centrifuged at $3500 \mathrm{~g}$ for $10 \mathrm{~min}$, and supernatants were obtained. The activities of calcium adenosine triphosphatase $\left(\mathrm{Ca}^{2+}\right.$-ATPase), sodium-potassium adenosine triphosphatase $\left(\mathrm{Na}^{+}-\mathrm{K}^{+}\right.$-ATPase $)$and calcium-magnesium adenosine triphosphatase $\left(\mathrm{Ca}^{2+}-\mathrm{Mg}^{2+}\right.$-ATPase $)$ in the hippocampus were assayed at a wavelength of $636 \mathrm{~nm}$. All procedures were performed according to the manufacturer's protocols. The concentration of protein was assessed by Coomassie Brilliant Blue method [18].

\section{$\mathrm{Ca}^{2+}$ concentration detection}

Calcium concentration was determined by Fura-2AM probe as described by Hiroshi et al. [19]. Briefly, 4 male and female rats were randomly chosen from each group and killed. After the hippocampus was isolated and weighted, $10 \times$ ice-cold sucrose solution $(0.32 \mathrm{~mol} / \mathrm{l})$ was added and rinsed at $4^{\circ} \mathrm{C}$. The tissue homogenates were 
centrifuged at $1500 \mathrm{~g}$ for $10 \mathrm{~min}$, and the supernatants were obtained. Subsequently, $2 \mathrm{ml}$ sucrose solution (1.20 mol/l) was added in the supernatant and then centrifuged at $40000 \mathrm{~g}$ for $20 \mathrm{~min}$. Diluted intermediate band with sucrose solution $(0.32 \mathrm{~mol} / \mathrm{l})$ and $2 \mathrm{ml}$ sucrose $(0.8 \mathrm{~mol} / \mathrm{l})$ were added slowly, and further centrifuged at $40000 \mathrm{~g}$ for $20 \mathrm{~min}$. The sediment was synaptosome.

The synaptosomes cultured on the coverglass were incubated with $2 \mu \mathrm{M}$ Fura-2/AM for $20 \mathrm{~min}$ at room temperature. Each coverglass was placed under a fluorescence microscope and perfused with the phosphate buffered saline (PBS) buffer containing $20 \mathrm{mM}$ 4-(2-hydroxyerhyl) piperazine-1-erhanesulfonic acid (HEPES), $115 \mathrm{mmol} \mathrm{so-}$ dium chloride $(\mathrm{NaCl}), 5.4 \mathrm{mmol}$ potassium chloride $(\mathrm{KCl})$, $1 \mathrm{mmol}$ magnesium chloride $(\mathrm{MgCl} 2), 1 \mathrm{mmol}$ calcium chloride $(\mathrm{CaCl} 2)$, and $10 \mathrm{mmol}$ glucose, $\mathrm{pH}=7.4$. The $\mathrm{ab}$ sorbance was measured by a Hitachi-850 fluorescence spectrophotometer with excitation wavelength at $350 \mathrm{~nm}$ and emission wave length at $340 \mathrm{~nm}$.

\section{ROS content detection}

After the hippocampus homogenates had been obtained, $10 \mu l$ 2,7-dichlorofuorescin diacetate (DCFH-DA) solution $(1 \mathrm{mmol} / \mathrm{l})$ was added and then incubated for $30 \mathrm{~min}$ at $37^{\circ} \mathrm{C}$. The absorbance was measured by a fluorescence spectrophotometer with excitation wavelength at $500 \mathrm{~nm}$ and emission wave length at $485 \mathrm{~nm}$. The concentration of protein was assessed by means of the Coomassie Brilliant Blue method.

\section{Statistical analysis}

Statistical analyses were carried out by using SPSS version 17.0 (SPSS, Inc., Chicago, IL, USA). Data was presented as the mean $(\mathrm{M}) \pm$ standard deviation (SD). The 2-, 3-factor and the repeated measure analysis of variance (ANOVA) were applied, and the Fisher's least significant difference (LSD) t-test used as the ANOVAs was significant. If the data proved heterogeneity of variance, the non-parametric Kruskal-Wallis test was performed. P-value $<0.05$ was accepted as evidence of significance.

\section{RESULTS}

\section{Animal general observation}

Few rats of $2 \mathrm{mg} / \mathrm{kg} \mathrm{B}(\mathrm{a}) \mathrm{P}$ group appeared to experience declined activity and retarded weight growth after B(a)P exposure for 3 days. No significant changes in the body weight were found in other groups. The number of rats gradually increased with the exposure time prolonged. Moreover, all the rats in $2 \mathrm{mg} / \mathrm{kg} \mathrm{B}(\mathrm{a}) \mathrm{P}$ group appeared to prove the above situation on 14th day after exposure, while few rats of $0.2 \mathrm{mg} / \mathrm{kg} \mathrm{B}(\mathrm{a}) \mathrm{P}$ group appeared to prove the same situation. No obvious abnormality was found in $0.02 \mathrm{mg} / \mathrm{kg} \mathrm{B}(\mathrm{a}) \mathrm{P}$ group and control groups.

\section{Hidden platform test}

In the hidden platform test, there was no significant effect on the gender of escape latency (treatment $x$ gender: $p>0.05)$. Thus, all rats were examined together. The results showed that, as compared with B(a)P-treated groups, the slope of escape latency in the control groups dropped faster with the increasing training days, and it reached almost a plateau on day 4 . However, as compared with the control groups, the escape latency was significantly higher in the $\mathrm{B}(\mathrm{a}) \mathrm{P}$ treated groups $(\mathrm{F}(4,75)=14.262$, $\mathrm{p}<0.05$ ) (Figure 1).

\section{Probe test}

The ability of spatial memory was typically reflected by the residence time in the target quadrant and the number of crossing platform. The result of the probe test showed that the number of the crossing platform and the time spent in the target quadrant of $\mathrm{B}(\mathrm{a}) \mathrm{P}$-treated groups were significantly decreased $(\mathrm{F}(4,75)=8.684$ and $\mathrm{F}(4,75)=10.437, \mathrm{p}<0.05)$ when compared with the control groups (Figure 2). 


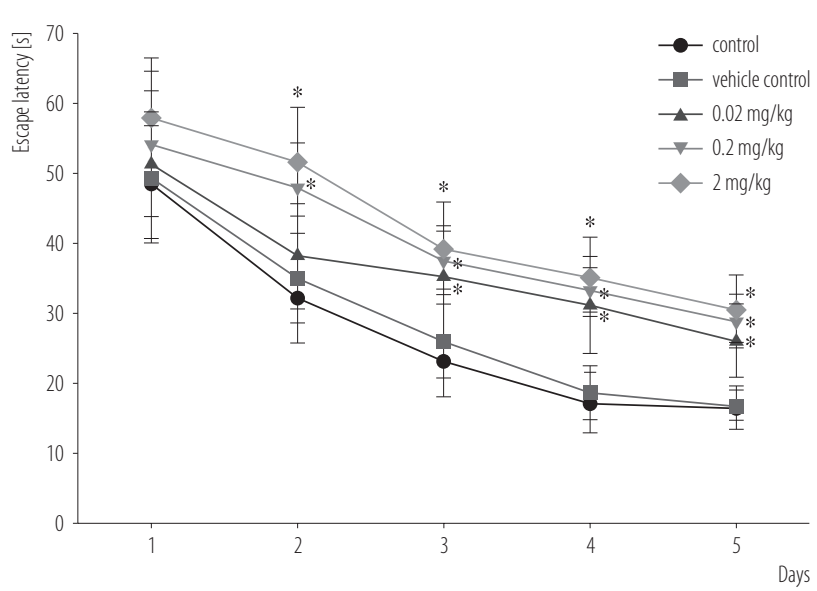

Data is presented in terms of the mean \pm standard error of mean $(\mathrm{M} \pm \mathrm{SEM})$.

$* p<0.05-$ significant difference from control group.

Fig. 1. The escape latencies of Morris water maze (MWM) after exposure to benzo(a)pyrene (B(a)P) of neonatal rats in the hidden platform $(\mathrm{N}=12)$

\section{ATPase activity}

The results of ATPase activity showed that $\mathrm{B}(\mathrm{a}) \mathrm{P}$ exposure had no significant effect on the ATPase activity between the gender (treatment $\times$ gender: $\mathrm{p}>0.05)$. Our results showed that the $\mathrm{Na}^{+}-\mathrm{K}^{+}$-ATPase

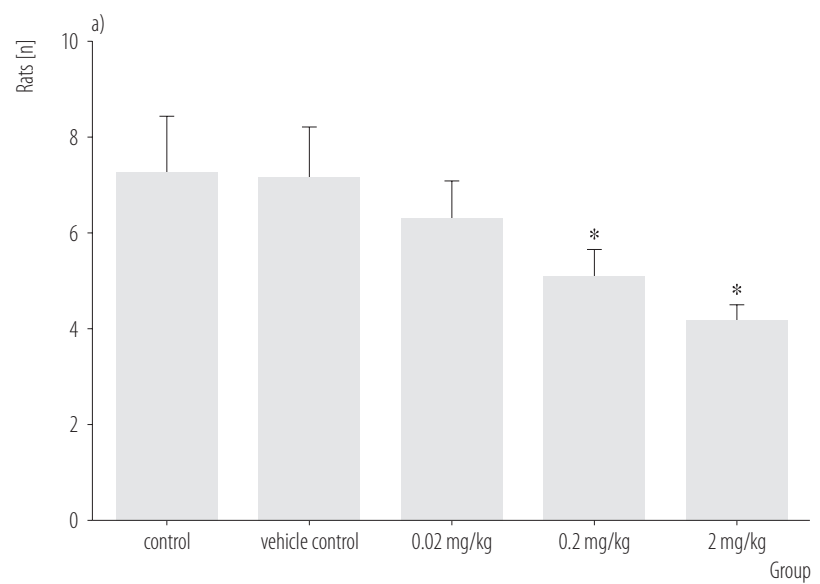

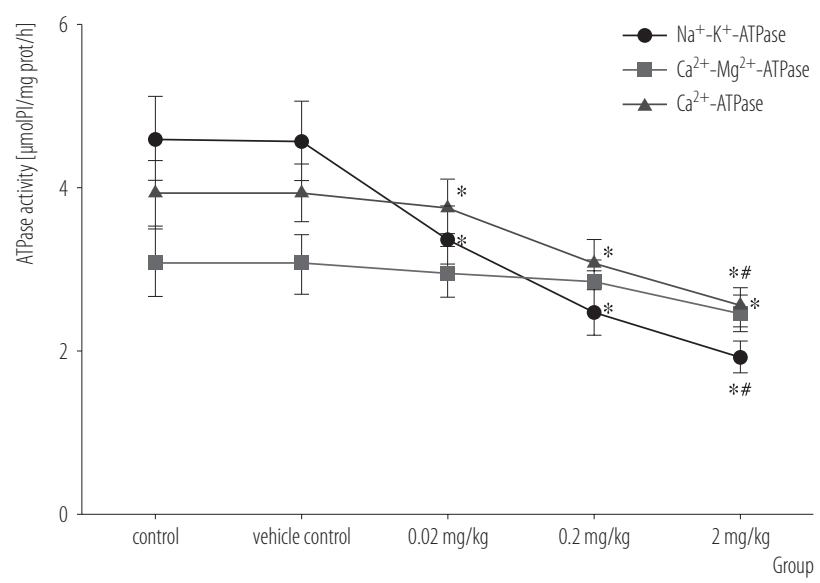

Data is presented in terms of the mean \pm standard error of mean $(\mathrm{M} \pm \mathrm{SEM})$.

$* \mathrm{p}<0.05$ - significant difference in the control group; ${ }^{\#} \mathrm{p}<0.01$ - significant difference in the $(\mathrm{B}(\mathrm{a}) \mathrm{P})$ medium-exposed group.

Fig. 3. Effects of benzo(a)pyrene (B(a)P) on adenosine triphosphatase (ATPase) activity in neonatal rats $(\mathrm{N}=8)$

activity, $\mathrm{Ca}^{2+}-\mathrm{Mg}^{2+}$-ATPase activity and $\mathrm{Ca}^{2+}$-ATPase activity in the $2 \mathrm{mg} / \mathrm{kg} \mathrm{B}(\mathrm{a}) \mathrm{P}$-treated group were significantly decreased as compared with the control group. Furthermore, the ATPase activity showed a significant decrease with the increasing doses of $\mathrm{B}(\mathrm{a}) \mathrm{P}(\mathrm{p}<0.05)$ (Figure 3).

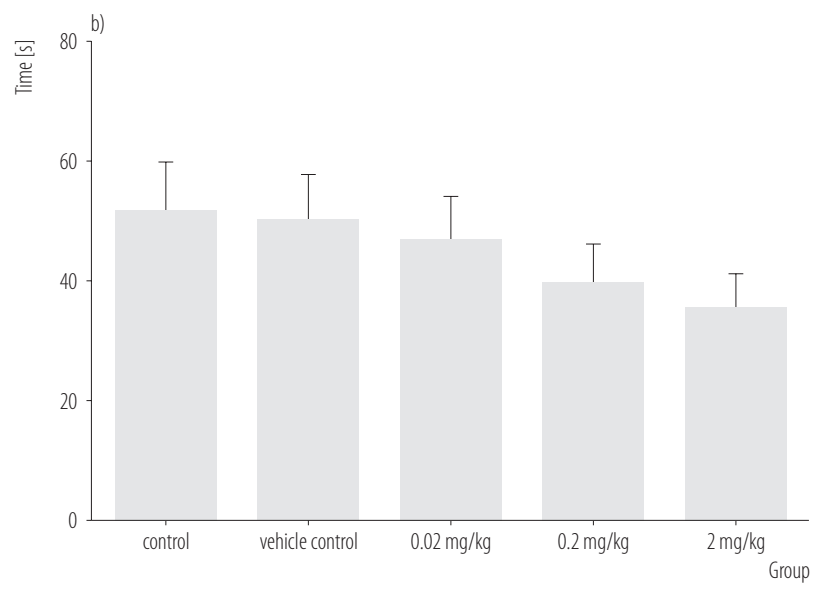

Data is presented in terms of the mean \pm standard error of mean $(\mathrm{M} \pm \mathrm{SEM})$. $* p<0.05-$ significant difference from control group.

Fig. 2. Effects of benzo(a)pyrene $(\mathrm{B}(\mathrm{a}) \mathrm{P})$ on neurobehavioral function of neonatal rats in the probe test $(\mathrm{N}=12)$ : $\mathrm{a})$ rats crossing platform in target quadrant, $b$ ) time spent in target quadrant 

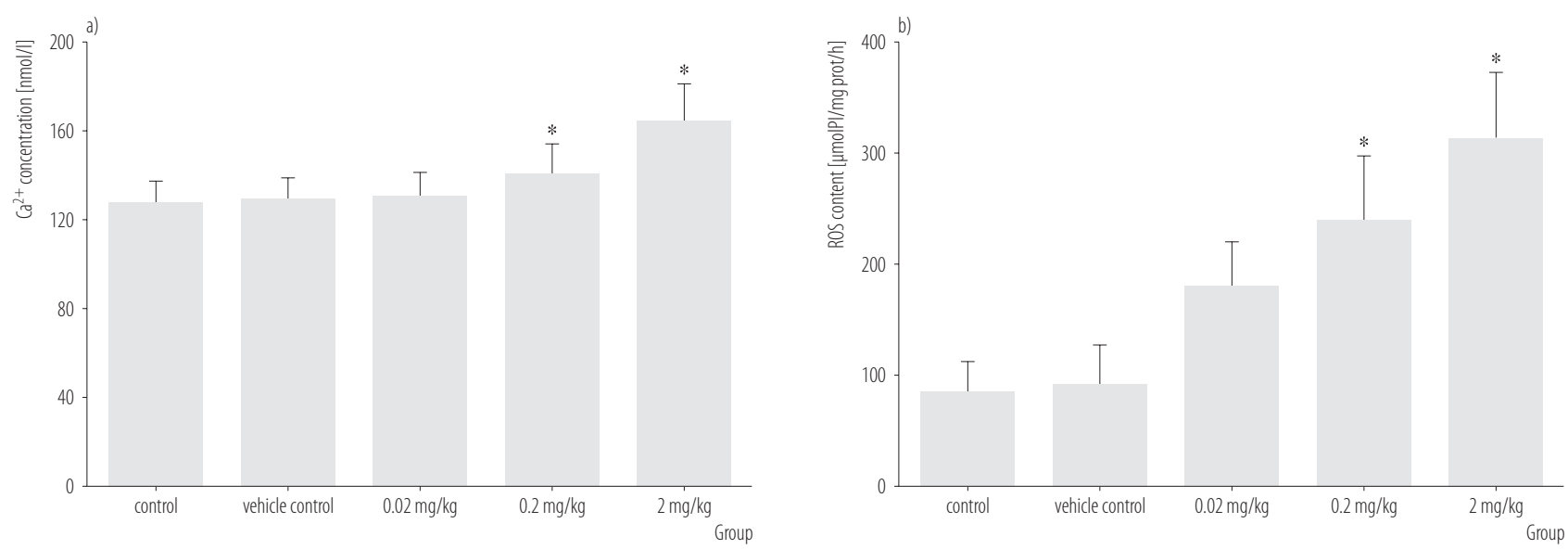

Data is presented in terms of the mean \pm standard error of mean $(\mathrm{M} \pm \mathrm{SEM})$. $* \mathrm{p}<0.05$.

Fig. 4. Effects of a) benzo(a)pyrene (B(a)P) on calcium $\left(\mathrm{Ca}^{2+}\right)$ concentration in the hippocampus, b) B(a)P on reactive oxygen species (ROS) concentration in the hippocampus

\section{$\mathrm{Ca}^{2+}$ and ROS content}

As shown in the Figure 4, the concentration of $\mathrm{Ca}^{2+}$ and ROS showed no significant difference in the gender in $\mathrm{B}(\mathrm{a}) \mathrm{P}$ exposed groups (treatment $\times$ gender: $\mathrm{p}>0.05$ ). The $\mathrm{Ca}^{2+}$ and $\mathrm{ROS}$ concentration increased significantly in $0.2 \mathrm{mg} / \mathrm{kg}$ and $2 \mathrm{mg} / \mathrm{kg} \mathrm{B}(\mathrm{a}) \mathrm{P}$-treated group. Moreover, the concentration of $\mathrm{Ca}^{2+}$ and ROS in the synapse increased with the increasing doses of $\mathrm{B}(\mathrm{a}) \mathrm{P}(\mathrm{p}<0.05)$.

\section{DISCUSSION}

Benzo(a)pyrene, as lipophilic organic compounds, may easily assemble in the lipid composition containing tissues, especially in the neural tissue. Importantly enough, B(a)P may also permeate the blood-brain barrier and then enter the CNS. Previous studies have indicated that B(a)P exposure causes the alteration of neuromotor behaviors and induces the impairment in the hippocampus [4,6,20,21]. The neonatal period is the critical period of brain development, the proliferation of nerve cells, hippocampal granule cells and the formation of synaptic and myelination usually reach the growth spurt on PND 20. Moreover, the brain tissue is sensitive for the neurotoxic effects in the neonatal rats [22-25]. Thus, in this study, the neonatal SD rats on PND 4 to 25 were chosen for B(a)P acute exposure and the effects on neurodevelopment were investigated.

Environment hazards on the function of nervous system dysfunction occurred much earlier than pathological damage, manifested by neurobehavioral function changes. The MWM is a classical method for studying the learning, memory, spatial orientation and cognitive ability of mice. Our findings have revealed that the escape latency increases while the number of crossing platform and time spent in target quadrant is decreased by $\mathrm{B}(\mathrm{a}) \mathrm{P}$ as compared to control groups, indicating that the spatial memory is impaired in the rats exposed to $\mathrm{B}(\mathrm{a}) \mathrm{P}$. These results are in agreement with Bouayed [26] who has reported that B(a)P exposure induces the impairments in the behavioral function of neonatal rats. Our data also reflects that the neurotoxic effects of $\mathrm{B}(\mathrm{a}) \mathrm{P}$ are restricted to $0.2 \mathrm{mg} / \mathrm{kg}$ and $2 \mathrm{mg} / \mathrm{kg}$ of $\mathrm{B}(\mathrm{a}) \mathrm{P}$. Adenosine triphosphatase, a protease on the biofilm, exists in the histiocyte and organelle membranes and plays an important role in the substance transportation, energy conversion and information transmission [27]. Calcium adenosine triphosphatase and calcium-magnesium 
adenosine triphosphatase also play a critical role in intracellular $\mathrm{Ca}^{2+}$ homeostasis. The decreased activity of ATPase may reduce the transport capacity of $\mathrm{Ca}^{2+}$, and then result in the formation of intracellular and extracellular $\mathrm{Ca}^{2+}$ concentration gradient as well as the balance of $\mathrm{Ca}^{2+}$ pump in the cytosol. Once this process is interrupted, it may further lead to the disturbance of cellular calcium homeostasis and forming $\mathrm{Ca}^{2+}$ overload [28]. The increased $\mathrm{Ca}^{2+}$ concentration within the cells could also compete with $\mathrm{Mg}^{2+}$ binding sites, and thus inhibit sodium-potassium adenosine triphosphatase and calciummagnesium adenosine triphosphatase activity. Our results have shown that the ATPase activities are significantly decreased with increasing doses of B(a)P.

Calcium, as a second messenger, may mediate neurotransmitter release and neurotrophic factor response [29-31]. Calcium also plays a pivotal role in many inter- and intraneuronal processes, such as neurotransmission, gene transcription, neurodegeneration, and neurodevelopment [32-35]. Also is $\mathrm{Ca}^{2+}$ an important nervous impulse conducting medium, and the concentration of $\mathrm{Ca}^{2+}$ will or will not significantly affect the nerve impulse conduction success. In this study we have observed that the concentration of $\mathrm{Ca}^{2+}$ in the synapse significantly increases in $0.2 \mathrm{mg} / \mathrm{kg}$ and $2 \mathrm{mg} / \mathrm{kg} \mathrm{B}$ (a)P-exposed group, which is in agreement with the data of Patri et al. [36] demonstrating that the neurodevelopmental impairments are mediated by elevated intracellular $\mathrm{Ca}^{2+}$ in the neuron. Thus, we have proposed that the modulation of $\mathrm{Ca}^{2+}$ levels could be a potential strategy for the prevention of $\mathrm{B}(\mathrm{a}) \mathrm{P}$ neurotoxicity but the detailed mechanisms should be further investigated in the future.

There is a close link between excitatory toxicity and oxidative damage. The increase in the ROS may be caused by the increase in excitatory toxicity, meanwhile the oxidative damage may also aggravate the excitatory toxicity [37]. The hyperactivity of neural cells leads to the increase in $\mathrm{Ca}^{2+}$ concentration, then the increase in the ROS generation through the series of ways. In turn, the ROS may increase the $\mathrm{Ca}^{2+}$ level in cytoplasm and increase the excitability by mobilizing the release of $\mathrm{Ca}^{2+}$ in mitochondria. Rats exposed to B(a)P experience a significant decrease in learning and memory ability and ATPase activity, while they also experience the increase in the content of the ROS and $\mathrm{Ca}^{2+}$. The reason may be that $\mathrm{B}(\mathrm{a}) \mathrm{P}$ exposure could cause oxidative stress, resulting in excessive of free radicals, leading to $\mathrm{Ca}^{2+}$ overload, then cause the dysfunction of energy and metabolism of nerve cells, eventually leading to learning and memory deficits.

\section{CONCLUSIONS}

Our study has shown that acute postnatal B(a)P exposure could induce the reduction of sodium-potassium adenosine triphosphatase, calcium-magnesium adenosine triphosphatase and $\mathrm{Ca}^{2+}$-ATPase activity, cause the $\mathrm{Ca}^{2+}$ overload in the synapse, and thus leading to the neurobehavioral impairments. These results also indicate that the reduction of ATPase activity and $\mathrm{Ca}^{2+}$ overload of hippocampal tissue in the neonatal rats may be the potential mechanism for nervous system impairment after having been exposed to $\mathrm{B}(\mathrm{a}) \mathrm{P}$.

\section{REFERENCES}

1. Staniszewska M, Graca B, Bełdowska M, Saniewska D. Factors controlling benzo(a)pyrene concentration in aerosols in the urbanized coastal zone. A case study: Gdynia, Poland (Southern Baltic Sea). Environ Sci Pollut Res Int. 2013;20(6): 4154-63, https://doi.org/10.1007/s11356-012-1315-0.

2. Jeng HA, Bocca SM. Influence of exposure to benzo[a]pyrene on mice testicular germ cells during spermatogenesis. J Toxicol. 2013;2013:387850, https://doi.org/10.1155/2013/387850.

3. Brown LNA, Khousbouei H, Goodwin JS, Irvin-Wilson CV, Ramesh A, Sheng L, et al. Down-regulation of early ionotrophic glutamate receptor subunit developmental expression as a mechanism for observed plasticity deficits following gestational exposure to benzo(a)pyrene. Neurotoxicology. 2007;28(5):965-78, https://doi.org/10.1016/j.neuro. 2007.05.005. 
4. Qiu C, Cheng S, Xia Y, Peng B, Tang Q, Tu B. Effects of subchronic benzo(a)pyrene exposure on neurotransmitter receptor gene expression in the rat hippocampus related with spatial learning and memory change. Toxicology. 2011;289 (2-3):83-90, https://doi.org/10.1016/j.tox.2011.07.012.

5. Perera FP, Tang D, Wang S, Vishnevetsky J, Zhang B, Diaz D, et al. Prenatal polycyclic aromatic hydrocarbon (PAH) exposure and child behavior at age 6-7 years. Environ Health Perspect. 2012;120(6):921-6, https://doi.org/10.1289/ ehp.1104315.

6. Chen C, Tang Y, Jiang X, Qi Y, Cheng S, Qiu CY, et al. Early postnatal benzo(a)pyrene exposure in Sprague-Dawley rats causes persistent neurobehavioral impairments that emerge postnatally and continue into adolescence and adulthood. Toxicol Sci. 2012;125(1):248-61, https://doi.org/10.1093/toxsci/kfr265.

7. McCallister MM, Maguire M, Ramesh A, Aimin Q, Liu S, Khoshbouei $\mathrm{H}$, et al. Prenatal exposure to benzo(a)pyrene impairs later-life cortical neuronal function. Neurotoxicology. 2008;29(5):846-54, https://doi.org/10.1016/j.neuro.2008. 07.008 .

8. Perera FP, Li Z, Whyatt R, Hoepner L, Wang S, Camann D, et al. Prenatal airborne polycyclic aromatic hydrocarbon exposure and child IQ at age 5 years. Pediatrics. 2009;124(2): e195-202, https://doi.org/10.1542/peds.2008-3506.

9. Yuan Y, Jiang CY, Xu H, Sun Y, Hu FF, Bian JC, et al. Cadmium-induced apoptosis in primary rat cerebral cortical neurons culture is mediated by a calcium signaling pathway. PloS One. 2013;8(5):e64330, https://doi.org/10.1371/journal. pone. 0064330 .

10. Berridge MJ, Bootman MD, Roderick HL. Calcium signalling: Dynamics, homeostasis and remodelling. Nat Rev Mol Cell Biol. 2003;4(7):517-29, https://doi.org/10.1038/ nrm1155.

11. Clapham DE. Calcium signaling. Cell. 2007;131(6):1047-58, https://doi.org/10.1016/j.cell.2007.11.028.

12. Heusinkveld HJ, Molendijk J, van den Berg M, Westerink RH. Azole fungicides disturb intracellular $\mathrm{Ca}^{2+}$ in an additive manner in dopaminergic PC12 cells. Toxicol Sci. 2013;134(2):374-81, https://doi.org/10.1093/toxsci/kft119.

13. Gu F, Fu L, Ma YJ. Functional analysis of calcium channelmediated exocytosis in synaptic terminals by FM imaging technique. Neurosci Bull. 2009;25(4):216-20, https://doi. org/10.1007/s12264-009-0507-1.

14. Duan L, Tang Y, Chen CZ, Pen B, Qiu CY, Qi YB, et al. [Effects of benzo(a)pyrene exposure on oxidative stress and ATPase in the hippocampus of rats]. Zhonghua Lao Dong Wei Sheng Zhi Ye Bing Za Zhi. 2013;31(7):500-3. Chinese.

15. Jiang Y, Zhou X, Chen X, Yang G, Wang Q, Rao K, et al. Benzo(a)pyrene-induced mitochondrial dysfunction and cell death in p53-null Hep3B cells. Mutat Res. 2011;726(1): 75-83, https://doi.org/10.1016/j.mrgentox.2011.08.006.

16. Li R, Zuo Z, Chen D, He C, Chen R, Chen Y, et al. Inhibition by polycyclic aromatic hydrocarbons of ATPase activities in Sebastiscus marmoratus larvae: Relationship with the development of early life stages. Mar Environ Res. 2011;71(1): 86-90, https://doi.org/10.1016/j.marenvres.2010.11.002.

17. Ziemann U, Hallett M, Cohen LG. Mechanisms of deafferentation-induced plasticity in human motor cortex. J Neurosci. 1998;18(17):7000-7.

18. Bradford MM. A rapid and sensitive method for the quantitation of microgram quantities of protein utilizing the principle of protein-dye binding. Anal Biochem. 1976;72:248-54, https://doi.org/10.1016/0003-2697(76)90527-3.

19. Hiroshi S, Yoichi S, Waka O, Shigeyasu T, Kojima I. Dissection of GLUT4 recycling pathway into exocytosis and endocytosis. J Biol Chem. 1995;270:11489-95, https://doi. org/10.1074/jbc.270.19.11489.

20. Schellenberger MT, Grova N, Farinelle S, Willième $S$, Schroeder H, Muller CP. Modulation of benzo[a]pyrene induced neurotoxicity in female mice actively immunized with a B[a]P-diphtheria toxoid conjugate. Toxicol Appl Pharmacol. 2013;271(2):175-83, https://doi.org/10.1016/j.taap. 2013.05.007.

21. Qi YB, Chen CZ, Tang Y, Jiang XJ, Qi CY, Peng B, et al. The synergistic effect of benzo[a]pyrene and lead on learn- 
ing and memory of mice. Toxicol Ind Health. 2013;29(5):38795, https://doi.org/10.1177/0748233711433932.

22. Saunders CR, Das SK, Ramesh A, Shockley DC, Mukherjee S. Benzo(a)pyrene-induced acute neurotoxicity in the F-344 rat: Role of oxidative stress. J Appl Toxicol. 2006;26(5):427-38, https://doi.org/10.1002/jat.1157.

23. Abraham H, Vincze A, Jewgenow I, Veszpremi B, Kravjak A, Gomori E, et al. Myelination in the human hippocampal formation from midgestation to adulthood. Int J Dev Neurosci. 2010;28(5):401-10, https://doi.org/10.1016/ j.ijdevneu.2010.03.004.

24. Edwards SC, Jedrychowski W, Butscher M, Camann D, Kieltyka A, Mroz E, et al. Prenatal exposure to airborne polycyclic aromatic hydrocarbons and children's intelligence at 5 years of age in a prospective cohort study in Poland. Environ Health Perspect. 2010;118(9):1326-31, https://doi. org/10.1289/ehp.0901070.

25. Whishaw IQ, Kolb B. Tongue protrusion mediated by spared anterior ventrolateral neocortex in neonatally decorticate rats: Behavioral support for the neurogenetic hypothesis. Behav Brain Res. 1989;32(2):101-13, https://doi.org/10.1016/ S0166-4328(89)80078-6.

26. Bouayed J, Desor F, Rammal H, Kiemer AK, Tybl E, Schroeder $\mathrm{H}$, et al. Effects of lactational exposure to benzo[alpha]pyrene $(\mathrm{B}[\mathrm{alpha}] \mathrm{P})$ on postnatal neurodevelopment, neuronal receptor gene expression and behaviour in mice. Toxicology. 2009;259(3):97-106, https://doi.org/10.1016/j.tox.2009.02.010.

27. Villa RF, Ferrari F, Gorini A. Effect of in vivo L-acetylcarnitine administration on ATP-ases enzyme systems of synaptic plasma membranes from rat cerebral cortex. Neurochem Res. 2011;36(8):1372-82, https://doi.org/10.1007/s11064-011-0462-x.

28. Fujita T, Inoue H, Kitamura T, Sato N, Shimosawa T, Maruyama N. Senescence marker protein-30 (SMP30) rescues cell death by enhancing plasma membrane $\mathrm{Ca}^{2+}$-pumping activity in Hep G2 cells. Biochem Biophys Res Commun. 1998;250(2):374-80, https://doi.org/10.1006/bbrc.1998.9327.
29. Neher E, Sakaba T. Multiple roles of calcium ions in the regulation of neurotransmitter release. Neuron. 2008;59(6): 861-72, https://doi.org/10.1016/j.neuron.2008.08.019.

30. Cheng A, Wang S, Yang D, Xiao R, Mattson MP. Calmodulin mediates brain-derived neurotrophic factor cell survival signaling upstream of Akt kinase in embryonic neocortical neurons. J Biol Chem. 2003;278(9):7591-9, https://doi. org/10.1074/jbc.M207232200.

31. Surmeier DJ, Guzman JN, Sanchez-Padilla J. Calcium, cellular aging, and selective neuronal vulnerability in Parkinson's disease. Cell Calcium. 2010;47(2):175-82, https://doi. org/10.1016/j.ceca.2009.12.003.

32. Carrasco MA, Hidalgo C. Calcium microdomains and gene expression in neurons and skeletal muscle cells. Cell Calcium. 2006;40(5-6):575-83, https://doi.org/10.1016/j.ceca.2006.08.021.

33. Mattson MP. Parkinson's disease: Don't mess with calcium. J Clin Invest. 2012;122(4):1195-8, https://doi.org/10.1172/ JCI62835.

34. Pravettoni E, Bacci A, Coco S, Forbicini P, Matteoli M, Verderio C. Different localizations and functions of L-type and N-type calcium channels during development of hippocampal neurons. Dev Biol. 2000;227(2):581-94, https://doi. org/10.1006/dbio.2000.9872.

35. Westerink RH. Targeting exocytosis: Ins and outs of the modulation of quantal dopamine release. CNS Neurol Disord Drug Targets. 2006;5(1):57-77, https://doi.org/10. 2174/187152706784111597.

36. Patri M, Singh A, Mallick BN. Protective role of noradrenaline in benzo[a]pyrene-induced learning impairment in developing rat. J Neurosci Res. 2013;91(11):1450-62, https:// doi.org/doi:10.1002/jnr.23265.

37. Amonpatumrat S, Sakurai H, Wiriyasermkul P, Khunweeraphong N, Nagamori S, Tanaka H, et al. L-glutamate enhances methylmercury toxicity by synergistically increasing oxidative stress. J Pharmacol Sci. 2008;108(3):280-9, https:// doi.org/10.1254/jphs.08118FP.

This work is available in Open Access model and licensed under a Creative Commons Attribution-NonCommercial 3.0 Poland License - http://creativecommons.org/ licenses/by-nc/3.0/pl/deed.en. 